\title{
Forensic Intelligence: Deregulation or Return to the Roots of Forensic
}

\section{Science?}

Olivier Ribaux ${ }^{1}$, Frank Crispino², Claude Roux ${ }^{3}$

1 Ecole des Sciences Criminelles, University of Lausanne, CH-1015 Lausanne, Switzerland, olivier.ribaux@unil.ch
2 Département Chimie, biochimie et physique, Université du Québec à Trois-Rivières, Canada, frank.crispino@uqtr.ca
3 Centre for Forensic Science, University of Technology, Sydney, Broadway NSW 2007, Australia, claude.roux@uts.edu.au

\section{Abstract}

This paper presents an overview of forensic intelligence through historical, operational and academic considerations. While forensic intelligence is thriving through new traceability of human activities, theoretical developments in policing and innovative technologies, it should mainly be seen as an opportunity for forensic science to contribute to make policing more 'scientific' in the broad sense. This paper supports the development of a modern framework to holistically use the information conveyed by forensic case data to inform policing processes, support decision making and ensure transparency. It is argued that the scientific information, the trace, has to be privileged, rather than rejected from current debates, despite the potential fears prompted by the misinterpretation of the term 'intelligence'. Ultimately, forensic intelligence enables the emergence of a modern conception of forensic science.

\section{Introduction}

Forensic intelligence brings challenges to the traditional forensic science laboratory already under pressure. This is particularly so for those who are dedicated to gain independence, better normalise and control their procedures, and provide high quality and impartial services focussed on the Court. However, errors are still detected, occasionally related to high profile cases. They inevitably cause expectations from the public on reinforcing procedures to prevent errors or detect them before leading to injustice and ultimately, a wrongful conviction. Unfortunately, as Rosenthal observed, 'It costs something to reduce errors, and it costs more and more to get rid of each error as there are fewer of them left' (Rosenthal 1978). End users are also impacted by that same system that does not look to invest more for the service. In short, it means that the laboratory is in a context of high pressure and asked to do more with fewer resources; it 
is approaching a breakpoint. This uncomfortable position is compounded by a series of studies that disseminate pervasive doubts upon the global effectiveness of forensic science (Brodeur 2010; Strom and Hickman 2010; White et al. 2011).

In fact, in the current paradigm, it might be that forensic science plays a tiny role in the whole process. Bob Milne (2012: 4) considers: ' $80 \%$ to $90 \%$ of forensic materials recovered never make their way into a forensic laboratory'. Milne continues by asking 'what are the ways that we can utilise this material to solve cases?'

It is in this context that this thing called 'forensic intelligence' enters into consideration. At first glance, it may be interpreted as demanding once again new efforts for the lab, without any guarantee to find new customers, open new profitable markets, and improve its position.

This overview takes a conversely optimistic view. It considers forensic intelligence as an opportunity to propose a new ambitious and enlarged project for forensic science by contributing to make policing more 'scientific' in the broad sense.

Actually, those who have kept close contacts with investigation despite the distancing of the laboratory during the last decade might not see intelligence as a genuine new development. They observe only the expression of an actual practice more overt in the scientific literature. However, what has changed is the emergence of a more proactive style of policing, as well as a broad variety of new ways to trace human activities. This kind of movement dramatically impacts forensic science, how it is perceived and what it is expected from it. There is a persuasive incentive to make an effort to better express how forensic science relates to policing through forensic intelligence.

\section{Old wine in new bottles?}

At its inception, forensic science was holistically combining all the accessible trace types, remnant of litigious activities, in order to provide accurate, timely and relevant information that supported responses to crime problems.

Indeed, pioneers in forensic science worked with a fully polyvalent vision of the trace that was supposed to support the global reconstruction of the case. However, Edmond Locard, the French criminalist, was soon to regret a move towards specialisation, at a time when fingerprint identification was dominating, similarly as DNA does today:

'Fingerprints are wonderful. I would say (...) it is privileged evidence. But, beyond, one can find prints of a variety of species: tooth print, nails, traces from the entire body, hair, 
dusts. Dust analysis is an infinite, unlimited resource. One can exactly know what the man did' ${ }^{1}$ (Locard 1955: 2)

This quote has obviously to be interpreted in its historical context, and within an evolving complex environment that articulates criminology, justice, and forensic science divergently through time and across countries (Kaminsky 1995). But Locard's argument is timeless and strategic. If one single trace attracts all the attention, offenders would know how to adapt their behaviour to suit. However, they would have difficulties to consciously control all the 'traceogenic' 2 aspects influencing the generation of traces of their movements within the environment imposed by typical criminal situations. Forensic intelligence has modernised this argument by integrating new traceability of human activities in virtual, numerical and economical worlds. This adds complexity to a point where offenders cannot know and manage all the possibilities of tracing their movements: it is not rare that the GPS integrated in an electronic device localises the stolen good or that thieves take a pictures of themselves with the stolen smart phone that is automatically sent to the victim (and the police) through the cloud! This notion prevailed in the US during the first part of the $20^{\text {th }}$ century, when the charismatic chief of the police of Berkeley, August Vollmer, managed to reform the police system (Vollmer and Schneider 1917; Vollmer 1930; Regional Oral History Office 1972, 1983). In line with the development of the first laboratory for the police, the school of criminology at University of Berkley emerged from the association of Vollmer with Paul Leland Kirk, the founder of Criminalistics, in 1950.

However, after a chaotic and politically agitated period, the school of criminology was closed in 1975, following the transfer of criminalistics to a scientific department, resulting in institutional distance from criminology. These events were the forerunner of the irresistible move towards a fragmented view, often focused on single type of trace and technique, which prevails in some laboratories and in most universities today.

\footnotetext{
${ }^{1}$ C'est magnifique les empreintes digitales. Je dirais (...) que c'est une preuve privilégiée. Mais en dehors de ça, on peut trouver des empreintes de toutes espèces de choses : des empreintes de dents, des empreintes d'ongles, des traces du corps tout entier, des cheveux, des poussières. L'analyse des poussières est une ressource infinie, illimitée (...) on peut savoir exactement ce que l'homme a fait'

${ }^{2}$ Prone to leave (physical and chemical) traces.
} 


\section{The withdrawal of forensic science}

The strong and general stream towards specialisation broke the already weak links between forensic science and the other fields that studied crime and led to draw increasingly strict distinctions between these fields. The resulting effect is the contemporary view of laboratories that offer services mostly dedicated to the Court (Kirk 1947, 1963a, 1963b; Holstrom 1972; MacCormick 1983). John DeHaan, reflected on these evolutions in the wake of the Californian disaster (DeHaan 2008). He rightly identified that the pioneers generalists of the 40s, 50 s and 60s had been progressively replaced by the 90 s generation of forensic scientists focusing on a specialty, and not appreciating 'the true role they play'. In the same address, he commemorated another great forensic intelligence scientist, Stuart Kind. Kind's book, entitled 'the Scientific Investigation of Crime', was published in 1987 (Kind 1987). It is one of the rare publication of this period that fully integrates forensic case data into the whole set of information treated in the course of crime investigation. Kind proposes many models, and expresses in his book the idea that good chemists or biologists cannot be de facto good support to the investigation if they do not understand their constraints, their precise objectives or underestimate the logical structure of crime investigation. In short, they bring little value to the investigation if they know nothing about the problem they are supposed to help solve.

As a sign of the influence of the current dominant conception of forensic science, Kind is almost never cited in the forensic literature, but is much more recognised as the initiator of geographical profiling through his seminal contribution to the Yorkshire Ripper investigation (Rossmo 1999).

DNA then submerged the holistic perspective in a single trace view of solving cases, tending to 'squeeze others out' (Robertson 2012: 87). The premises of forensic intelligence were diluted with this movement:

'We appear to have relegated the framing of questions to non-scientifically educated detectives leaving criminalists with technician functions and fancy hardware, operating in a reactive mode, doing only what is asked of them. This has certainly been the trend. When we take a good look at this model, to which we seem to have grown accustomed, does it make any sense? If the laboratory is set up on the clinical model and crime scenes are handled exclusively by non-scientists, there is no problem-solving scientist on the "front end' (De Forest 1999: 198) 
This stream has continued to progress in a changing economical environment that drove the emergence of private laboratories offering mostly technical services (Lawless 2010; Lawless 2011).

This model largely dominated the scientific literature by focusing both on the development of more rapid, sensitive, transportable and cheapest techniques, together with the development of evaluation frameworks carefully designed for the Court (Cook et al. 1998b; Cook et al. 1998a). In this context, it seems that there is no more room for a forensic intelligence approach to crime. This is a fallacy, as it is demonstrated in this article and other contributions of this special issue.

\section{The silent development of forensic intelligence}

Beyond some modern holistic view of forensic science that began at the Berkeley school (Inman and Rudin 2001), there has been a continued resistance or reconquer the territory lost by the initial movement, and which is driven by the specialisation process. It was recognised in the UK that a gap has widened between investigators and scientists when a Home Office inquiry led by Sir Lawrence Byford into the failure of the Yorkshire Ripper case (Byford 1981) acknowledged poor use of forensic case data to orient the investigation (Kind 1987). More than a decade later, concrete measures led to the creation of an investigative resource (i.e. National Crime Faculty, 1996) that fully included the so called 'Byford's scientists. These were senior forensic scientists able to coordinate, promote and ensure the proper use of forensic case data in major inquiries (Barclay 2009; Tilley and Townsley 2009). Parallels between the investigative and scientific method in the development programs of Senior Investigative Officers were then explicitly drawn (Barclay 2009). In 2005, the Parliamentary Select Committee 'Forensic Science on Trial' arrived at the conclusion that 'the main contribution that forensic science makes to the criminal justice system is the generation of intelligence to assist investigations' (House of Commons 2005: 8).

Simultaneously, unpublished practices were developed and fostered in many other jurisdictions, particularly where small police organisations co-exist with forensic units. This happened for example in Switzerland, due to its federalist structure and the relatively small size of police organisations. In such environments, there are numerous incentives to adopt a more collective approach between investigators and forensic scientists. This is confirmed by observations in evaluation studies about the 
effectiveness of forensic science: the integration of forensic case data is better when there is a collaborative approach; that is when close relationships between the different contributors who jointly solve problems is promoted (Bradbury and Feist 2005; Adderley et al. 2007; Kelty and Julian 2012; Rossy and Ribaux 2013). As most of the good practices belong to police organisations, very few seem to be published in the scientific literature in English. However, there are some signs of a more general change in the way the articulation between forensic science and crime investigation can be conceived. For instance, in France, the gap has been filled by members of the 'gendarmerie' who developed the concept of a crime scene coordinator, a new role, devised in particular to make the best use of information conveyed by forensic case data during specific investigations (Schuliar 2009). In Germany, the investigation of serious cases also seems to be much more team based, in integrating forensic case data (Dern et al. 2009). The framework proposed by Chisum and Turvey (2011) is another illustration of the same tendency to favour a collective interdisciplinary approach. Finally, laboratories themselves tend to develop functions such as the 'case manager' to take advantage of contextual information and protect scientists from biases (Thompson 2011). However, it is not clear how systematically and to what extent this function is actually implemented.

Beyond the creation of new organisational settings, some models, methods and enabling IT systems have begun to emerge. Examples of this are the combined used of forensic case data (Leary 2002), a framework for understanding the temporal structure of events (Weyermann and Ribaux 2012) or, more specifically, the extended use of DNA profiles for investigative and intelligence purposes, when partial profile or mixtures are extracted (Bieber et al. 2006; Hicks et al. 2010).

Of course, the concerns about how to more effectively use physical materials may already seem obsolete when the new traceability of human activities in retrospective or proactive investigations is considered. A broad variety and quantity of 'digital' traces is now commonly used, such as mobile phone data, geolocalisation, images, internet interceptions, or traces recovered from other electronic devices. They have already changed the nature of the contribution of forensic science in the early phase of the investigative process. The omnipresence of forensic science during crime investigation is a fact. However, trained generalists, models, and methods are either not available or 
not used appropriately to structure and evaluate the use of forensic case data at all stages of the process (Robertson 2012; Williams and Weetman 2013).

In this context, it is fair to say that most forensic science efforts are dedicated to reinforce the last step of the process: the court process. There is an imbalance that forensic intelligence aims to correct, by providing stronger information processing, inference and evaluative models for improving the rationality of the approach earlier than the ultimate phase, and prior to the point where poor decision-making is hardly recoverable. This should obviously include the crime scene as the first step in the process (Crispino 2008).

Beyond the involvement of forensic science in supporting and reinforcing crime investigation, Tilley and Ford (1996) pointed towards another question, even more problematic, about the proactive use of forensic case data in dealing with high volume crime. They proposed another great incentive for forensic intelligence to find a new position: the increasing awareness and implementation of proactive models of policing.

Proactive models of policing and their embarrassing questions to forensic sciences A mosaic of models has developed around the idea of switching from a reactive approach to policing to a more proactive approach, by better use of the collected information, analysed to focus strategies, operations and tactics, and support decisionmaking processes at every level of the organisation. One of the most prominent approaches was best expressed by Ratcliffe under the unifying term of intelligence-led policing (ILP) (Ratcliffe 2008: 89):

'Intelligence-Led policing is a business model and managerial philosophy where data analysis and crime intelligence are pivotal to an objective, decision-making framework that facilitates crime and problem reduction, disruption and prevention through both strategic management and effective enforcement strategies that target prolific and serious offenders'

The interpretation of such models based on a structured approach to security problems has proliferated (Brodeur 2010), and, even if ILP is now claimed to be the driving model of many organisations, it remains unclear to what extent it is really the case in actual practice.

Whatever the differences of conceptions, this movement has started to question the positioning and function of forensic science. 
How to evaluate efficiency in regard to these models of policing has become a recurrent point, placing more pressure on forensic science service providers (Bradbury and Feist 2005; Julian et al. 2011; Roux et al. 2014). From a traditional view of forensic science, the answer seems evident: forensic case data have a great potential for detecting crimes, and all the efforts of normalisation and standardisation would suggest some consistency of forensic science process across jurisdictions. Unfortunately, available studies continually show the contrary: the evaluation of the contribution of forensic science to crime detection rates in the end-to-end process, in particular for DNA, demonstrate systematically small returns in comparison to investment. They also indicate huge differences in the many decision making points along the process of collecting the trace, triaging, collating and using databases, and presenting evidence (Burrows and Tarling 2004; Rix 2004; Bradbury and Feist 2005; Adderley et al. 2007; Brodeur 2008; Schroeder and White 2009; Walsh 2009; Brodeur 2010; Wilson et al. 2010; White et al. 2011; Ludwig and Fraser 2013). In the authors' opinion, these studies do not show that forensic science and the use of its related technology (e.g. databases) are ineffective in policing, but rather that its contribution is poorly understood, formalised and largely diluted when the focus is only crime detection. This question is increasingly asked in the literature (Walsh et al. 2004; Bieber 2006; Walsh et al. 2009; Roux et al. 2014). Indeed, in a proactive style of policing, crime detection is one, but not the only relevant question. The focus should also be on crime reduction through prevention, disruption, and the improvement of the feeling of community security. How forensic science actually contributes to these objectives is far more complex to demonstrate (Burrows and Tarling 2004; Wilson et al. 2010), and much work on this perspective is still to be done. This will be difficult to achieve so long as the articulation of forensic science in these new models of policing remains poorly expressed. This is a crucial issue for forensic intelligence where there is burgeoning interest and activity.

\section{Forensic intelligence in a proactive style of policing}

An elementary task in a proactive style of policing consists of linking disparate pieces of information in order to obtain a whole picture for repetitive crime problems. Forensic case data has shown great potential for crime scene linking (Birkett 1989; Anthonioz et al. 2002; Napier 2002; Walsh et al. 2002; Dujourdy et al. 2003; Braga and Pierce 2004; Walsh and Buckleton 2004; Walsh et al. 2009; Rossy et al. 2013). However, the 
advantage of this approach has long been masked by the demand for individualising and directly implicating suspects. The approach to linking crimes has largely ignored the possible contribution of DNA technologies, (Bennell et al. 2012), and linking crimes through DNA is still often seen as a side effect of the use of databases but certainly not as a pillar of an intelligence-led strategy (Walsh 2009). This is about to change.

The experience presented by Braga (2008) makes clearer the possibilities of integrating forensic case data into problem-oriented policing. His crime prevention study was related to a strategy to mitigate violent gun crimes. Through the systematic comparisons of marks that firearms leave on bullets, different uses of the same gun were identified. These relationships oriented specific inquiries, and their integration with other accessible data was a determinant in the detection of a range of serious cases. The links have mostly been used to delineate the activity of different crime gangs within a city, and their operational territories. The larger picture allowed preventive operations towards groups that presented the more serious risks. The immediate detection of an emerging criminal activity provided a chance for a rapid intervention in order to avoid a spiralling effect. This study also showed that the police had changed their perception of the global problem which previously had no visibility. This case is a clear illustration of the need for a more systematically integrated approach to proactive policing projects, even at an international level (Gagliardi 2012). This view is supported by Crispino, who developed the idea and promoted an extended job definition for the crime scene coordinator to participation in proactive policing (Crispino 2006, 2009; Crispino et al. 2009).

The implementation of the National Intelligence Model in the UK, advocating an intelligence-led approach to policing, has had an impact on the extended use of information conveyed by traces in some key organisations, such as the Metropolitan Police in London (Milne 2012). However, it is an ongoing process to properly integrate forensic case data, as well as influence forensic operations when analysing serial crimes (Blakey 2002; Mennell and Shaw 2006; Ribaux et al. 2010a; Ribaux et al. 2010b). When a systematic linking process is operating over a long period, the full potential of forensic intelligence is clearly demonstrated not only for detecting specific series of crime, but also in providing a new vision of the structure of organised crime (Morelato et al. 2014). For instance, such approaches have been systematically implemented to detect and follow-up a variety of crime problems, such as high volume crimes (Rossy et 
al. 2013), illicit drug profiling (Ioset et al. 2005), counterfeit documents (Baechler et al. 2012) and National Security Problems (Johnston 2004).

\section{A new interest from some criminologists}

It appears we have come full circle and the link between forensic science and criminology is somewhat re-established. The trace, remnant of a criminal activity, when detected and recognised conveys the most elementary, transparent, measurable information of the crime itself (Margot 2011). Studies conducted by Lammers and his colleague $(2012 ; 2013 ; 2013)$ who use DNA linking for investigating questions such as how long serial offenders escape arrest, consideration about the criminal careers of offenders (Leary and Pease 2003) or about their mobility (Walsh 2009; Rossy et al. 2013), the analysis of waste water to analyse drug consumption (van Nuijs et al. 2011), as well as the realisation that there is links to be built between environmental criminology and crime scene investigation (Ribaux et al. 2010a), are examples of the criminological flavour of forensic intelligence. This is reinforced by the more integrative vision suggested by the emerging field of crime science (Pease 2010), as well as more comprehensive approach to forensic science (Fraser and Williams 2009) underpinning the 'shift from the traditional laboratory to the coal face of policing' (Technology 2011).

\section{Conclusion}

A modern conception of forensic science is emerging through forensic intelligence. It may be interpreted as old wine in new bottles if we analyse the separation of forensic science from criminology during the $20^{\text {th }}$ century, followed by a return towards more integration. However, the new traceability of human activities, theoretical development in policing, as well as innovative technologies drive this development as these areas badly need a modern framework to holistically use the information conveyed by forensic case data to inform policing processes, and support all the variety of decisions to be made. In the perspective of a bulimic treatment of big data in the society of information, and its potential weakening of civil liberties, such efforts are indispensable. The expression of models in forensic intelligence is necessary for ensuring transparency. It is particularly turned towards crime prevention in policing, when police are not necessarily leading such programs. It is not the monopoly of State's agencies. We argue that the scientific information, the trace, has to be privileged, rather than rejected from 
this debate, despite the potential fears prompted by the misinterpretation of the term 'intelligence'.

In this context, we ought to ask the question: could forensic intelligence be the saviour of forensic science?

\section{Bibliography}

Adderley, R., M. Townsley and J. Bond (2007) 'Use of Data Mining Techniques to Model Crime Scene Investigator Performance', Knowledge-based Systems Vol 20, 170176,

Anthonioz, A., A. Aguzzi, A. Girod, N. Egli and O. Ribaux (2002) 'Potential Use of Fingerprints in Forensic Intelligence : Crime Scene Linking', Problems of Forensic Sciences Vol 51, 166-170,

Baechler, S., P. Margot and O. Ribaux (2012) 'Toward a Novel Forensic Intelligence Model: Systematic Profiling of False Identity Documents', Forensic Science Policy and Management Vol 3 no 2, 70-84,

Barclay, D. (2009) 'Using Forensic Science in Major Crime Inquiries' in J. Fraser and R. Williams (eds), Handbook of Forensic Science, Willan, Cullompton, 337-358

Bennell, C., B. Snook, S. Macdonald, J. C. House and P. J. Taylor (2012) 'Computerized Crime Linkage Systems. A Critical Review and Research Agenda', Criminal Justice and Behavior Vol 39 no 5, 620-634, http://cjb.sagepub.com/content/39/5/620.abstract

Bieber, F. R. (2006) 'Turning Base Hits into Earned Runs: Improving the Effectiveness of Forensic DNA Data Bank Programs', The Journal of Law, Medicine \& Ethics Vol 34 no 2, 222-233, http://dx.doi.org/10.1111/j.1748-720X.2006.00029.x

Bieber, F. R., C. H. Brenner and D. Lazer $(2006)$ 'Finding Criminals Through DNA of Their Relatives', Science Vol 312 no 5778, 1315-1316,

Birkett, J. (1989) 'Scientific Scene Linking', Journal of the Forensic Science Society Vol 29, 271-284,

Blakey, D. (2002) Under the Microscope Refocused. A Revisit to the Thematic Inspection. Report on Scientific and Technical Support, Her Majesty's Inspectorate of Constabulary, Ditching

Bradbury, S.-A. and A. Feist (2005) The Use of Forensic Science in Volume Crime Investigations: a Review of the Research Literature, Online Report, Home Office, Londres, 43/05, http://www.homeoffice.gov.uk/publications/ (accédé le 4 janvier 2013)

Braga, A. A. (2008) 'Gun Enforcement and Ballistic Imaging Technology in Boston' in D. L. Cork, J. E. Rolph, E. S. Meieran and C. V. Petrie (eds), Ballistic Imaging, National Academies Press, Appendix A

Braga, A. A. and G. L. Pierce (2004) 'Linking Crime Guns: The Impact of Ballistics Imaging Technology on the Productivity of the Boston Police Department's Ballistics Units', Journal of Forensic Sciences Vol 49 no 4, 1-6,

Brodeur, J.-P. (2008) 'Scientific Policing and Criminal Investigation' in S. Leman-Langlois (eds), Technocrime: Technology, Crime and Social Control, Willan, Londres, 169193

Brodeur, J.-P. (2010) The Policing Web, Oxford University Press, New York

Burrows, J. and R. Tarling (2004) 'Measuring the Impact of Forensic Science in Detecting Burglary and Autocrime Offences', Science \& Justice Vol 44 no 4, 217-222, 
Byford, L. (1981) The Yorkshire Ripper Case: Review of the Police Investigation of the Case, Home Office, Her Majesty's Inspector of Constabulary, Londres

Chisum, W. J. and B. E. Turvey (2011) Crime Reconstruction, Elsevier Academic Press, Burlington

Cook, R., I. W. Evett, G. Jackson, P. J. Jones and J. A. Lambert (1998a) 'A Hierarchy of Propositions: Deciding which Level to Address in Casework', Science \& Justice Vol 38 no 4, 231-239,

Cook, R., I. W. Evett, G. Jackson, P. J. Jones and J. A. Lambert (1998b) 'A model for case assessment and interpretation', Science \&amp; Justice Vol 38 no 3, 151-156, http://www.sciencedirect.com/science/article/pii/S1355030698720994

Crispino, F. (2006) 'La trace matérielle. Un catalyseur d'exploitation de l'information judiciaire. ', Revue de la gendarmerie nationale no 221, 5-15,

Crispino, F. (2008) 'Nature and Place of Crime Scene Management within Forensic Sciences', Science \& Justice no 1, 24-28,

Crispino, F. (2009) 'L'interprétation des données de la scène de crime: une simple requête judiciaire?', Revue Internationale de Criminologie et de Police Technique et Scientifique no 1

Crispino, F., J. Brault and P. Burgueyre (2009) 'Le coordinateur en criminalistique: un nouvel acteur du renseignement criminel', Revue de la gendarmerie nationale no 233, 6-15,

De Forest, P. R. (1999) 'Recapturing the Essence of Criminalistics', Science \& Justice Vol 39 no 3, 196-208,

DeHaan, J. D. (2008) 'Stuart Kind memorial lecture', Science \& Justice Vol 48, 91-94,

Dern, H., C. Dern, A. Horn and U. Horn (2009) 'The Fire Behind the Smoke: A Reply to Snook and Colleagues', Criminal Justice and Behavior Vol 36 no 10, 1085-1090,

Dujourdy, L., G. Barbati, F. Taroni, O. Guéniat, P. Esseiva, F. Anglada and P. Margot (2003) 'Evaluation of links in heroin seizures', Forensic Science International Vol 131, 171-183,

Fraser, J. and R. Williams (2009) Handbook of Forensic Science, Willan, Cullompton

Gagliardi, P. (2012) 'Transnational organized crime and gun violence. A case for firearm forensic intelligence sharing', International Review of Law, Computers \& Technology Vol 26 no 1, 83-95, http://dx.doi.org/10.1080/13600869.2012.646801

Hicks, T., F. Taroni, J. M. Curran, J. Buckleton, O. Ribaux and V. Castella (2010) 'Use of DNA Profiles for Investigation Using a Simulated Swiss National DNA Database: Part I, Partial SGM Plus Profiles', Forensic Science International Genetics Vol 4 no 4, 232-248,

Holstrom, J. (1972) 'Vollmer as a Man: Memories of a Close Friend and Colleague' in R. 0. H. Office (eds), August Vollmer: Pioneer in Police Professionalism : Oral History Transcript / and Related Material, University of California, The Bancroft Library, Berkeley,Volume I

House of Commons (2005) Forensic Science on Trial Science and Technology Committee (eds), Seventh Report of Session 2004-05, http://www.publications.parliament.uk/pa/cm200405/cmselect/cmsctech/96/ 96i.pdf (accessed 10th of December 2013)

Inman, K. and N. Rudin (2001) Principles and Practice of Criminalistics: the Profession of Forensic Science, CRC Press LLC, Boca Raton

Ioset, S., P. Esseiva, O. Ribaux, C. Weyermann, F. Anglada, S. Lociciro, P. Hayoz, I. Baer, L. Gasté, Anne-LaureTerrettaz-Zufferey, C. Delaporte and P. Margot (2005) 
'Establishment of an Operational System for Drug Profiling: a Swiss Experience', Bulletin of Narcotics Vol 57 no 1-2, 121-146,

Johnston, D. (2004) 'Bomb Designs Hint at Global Network', NY Times

Julian, R. D., S. F. Kelty, C. Roux, P. Woodman, J. Robertson and P. Margot (2011) 'What is the Value of Forensic Science? An Overview of the Effectiveness of Forensic Science in the Australian Criminal Justice System Project', Australian Journal of Forensic Sciences Vol 43 no 4, 217-229,

Kaminsky, D. (1995) 'Une histoire à lire entre les mots: les mouvements de la criminologie', Déviance et Société Vol 19 no 4, 307-323,

Kelty, S. and R. Julian (2012) The 7 Key Attributes of Good Crime Scene Examiners: Brief Report, Tasmanian Institut of Law enforcement Studies, Tasmanian Institute of Law Enforcement Studies, Hobart

Kind, S. S. (1987) The Scientific Investigation of Crime, Forensic Science Services Ltd, Harrogate

Kirk, P. L. (1947) 'The Standardization of Criminological Nomenclature', Journal of Criminal Law and Criminology (1931-1951) Vol 38 no 2, 165-167, http://www.jstor.org/stable/1138912

Kirk, P. L. (1963a) 'Criminalistics', Science Vol 140 no 35, 367-370,

Kirk, P. L. (1963b) 'The Ontogeny of Criminalistics', The Journal of Criminal Law, Criminology and Police Science Vol 54, 235-238,

Lammers, M. (2013) 'Are Arrested and Non-Arrested Serial Offenders Different? A Test of Spatial Offending Patterns Using DNA Found at Crime Scenes ', Journal of Research in Crime and Delinquency doi: 10.1177/0022427813504097

Lammers, M. and W. Bernasco (2013) 'Are mobile offenders less likely to be caught? The influence of the geographical dispersion of serial offenders' crime locations on their probability of arrest', European Journal of Criminology Vol 10 no 2, 168-186

Lammers, M., W. Bernasco and H. Elffers (2012) 'How Long Do Offenders Escape Arrest? Using DNA Traces to Analyse When Serial Offenders Are Caught', Journal of Investigative Psychology and Offender Profiling Vol 9 no 1, 13-29, http://dx.doi.org/10.1002/jip.1353

Lawless, C. (2010) A Curious Reconstruction? The Shaping of 'Marketized' Forensic Science, The London School of Economics and Political Science, Centre for Analysis of Risk and Regulation, London

Lawless, C. J. (2011) 'Policing Markets: The Contested Shaping of Neo-Liberal Forensic Science', British Journal of Criminology Vol 51, 671-689,

Leary, D. and K. Pease (2003) 'DNA and the Active Criminal Population', Crime Prevention and Community Safety: An International Journal Vol 5, 7-12,

Leary, R. M. (2002) The Role of the National Intelligence model and "FLINTS" in Improving Police Performance. Paper written following a presentation at the Home Office/ACPO Conference, Leicestershire

Locard, E. (1955) 'Entretiens avec Edmond Locard', L. Zirone and M. Finidori

Ludwig, A. and J. Fraser (2013) 'Effective use of forensic science in volume crime investigations: Identifying recurring

themes in the literature', Science and Justice Vol in press

MacCormick, A. (1983) 'Education for the Profession, an Oral History conducted in 1972 by Gene Carte(eds), August Vollmer: Pioneer in Police Professionalism, The Bancroft Library, University of California, Regional Oral History Office, Berkeley,Volume II 
Margot, P. (2011) 'Forensic Science on Trial - What Is the Law of the Land?', Australian Journal of Forensic Sciences Vol 43 no 2, 89-103,

Mennell, J. and I. Shaw (2006) 'The Future of Forensic and Crime Scene Science Part I - A UK Forensic Science User and Provider Perspective', Forensic Science International Vol 157 no Supplement 1, S7-S12,

Milne, R. (2012) Forensic Intelligence, CRC, Boca Raton

Morelato, M., S. Baechler, O. Ribaux, A. Beavis, M. Tahtouh, P. Kirkbride, C. Roux and P. Margot (2014) 'Forensic Intelligence Framework. Part I: Induction of A Transversal Model by Comparing Illicit Drugs and False Identity Documents Monitoring', Forensic science international, Vol 236, 181-190.

Napier, T. J. (2002) 'Scene Linking Using Footwear Mark Database', Science \& Justice Vol 42 no $1,39-43$,

Pease, K. (2010) 'Crime Science' in Shlomo G. Shoham, P. Knepper and M. a. Kett (eds), International Handbook of Criminology, Taylor and Francis, 3-22

Ratcliffe, J. (2008) Intelligence-Led Policing, Willan, Cullompton, UK

Regional Oral History Office (1972) August Vollmer: Pioneer in Police Professionalism : Oral History Transcript / and Related Material, University of California, The Bancroft Library, Berkeley

Regional Oral History Office (1983) August Vollmer: Pioneer in Police Professionalism. An Oral History conducted in 1972 University of California, The Bancroft Library, Berkeley

Ribaux, O., A. Baylon, E. Lock, C. Roux, O. Delémont, C. Zingg and P. Margot (2010a) 'Intelligence-led Crime Scene Processing. Part II: Intelligence and Crime Scene Examination ', Forensic Science International Vol 199, 63-71, doi:10.1016/j.forsciint.2009.10.027

Ribaux, O., A. Baylon, C. Roux, O. Delémont, E. Lock, C. Zingg and P. Margot (2010b) 'Intelligence-led Crime Scene Processing. Part I: Forensic Intelligence', Forensic Science International Vol 195 no 1, 10-16, doi:10.1016/j.forsciint.2009.10.027

Rix, B. (2004) The Contribution of Shoemark Data to Police Intelligence, Crime Detection and Prosecution, Findings Home Office, Research, Development and Statistics Directorate, London, 236, http://www.homeoffice.gov.uk/rds/pdfs04/r236.pdf (accédé le 4 janvier 2013)

Robertson, J. (2012) 'Forensic science, an Enabler or Disenabler for Criminal Investigation?', Australian Journal of Forensic Sciences Vol 44 no 1, 83-91,

Rosenthal, R. (1978) ' How often Are our Numbers Wong? ', American Psychologist Vol 33 no 11, 1005-1008,

Rossmo, K. (1999) Geographical Profiling, CRC Press, Boca Raton

Rossy, Q., S. Ioset, D. Dessimoz and O. Ribaux (2013) 'Integrating Forensic Information in a Crime Intelligence Database', Forensic Science International Vol 230, 137-146,

Rossy, Q. and O. Ribaux (2013) 'A Collaborative Approach for Forensic Science and Investigation Using Criminal Intelligence Analysis and Visualisation', Science and Justice, in press.

Roux, C., R. Julian, S. Kelty and O. Ribaux (2014) 'Forensic Science Effectiveness' in G. Bruinsma and D. Weisburd (eds), Encyclopedia of Criminology \& Criminal Justice Springer, Berlin, 1795-1804

Schroeder, D. A. and M. D. White (2009) 'Exploring the Use of DNA Evidence in Homicide Investigations', Police Quarterly Vol 12 no 3, 319-342, http://pqx.sagepub.com/content/12/3/319.abstract 
Schuliar, Y. (2009). La coordination scientifique dans les investigations criminelles. Proposition d'organisation, aspects éthiques ou de la nécessité d'un nouveau métier Doctoral dissertation, Université Paris 5 - Descartes Faculté de Médecine and Université de Lausanne, Institut de Police Scientifique, Paris et Lausanne

Strom, K. J. and M. J. Hickman (2010) 'Unanalyzed Evidence in Law Enforcement Agencies', Criminology \& Public Policy Vol 9, 381-404,

Technology, H. S. a. (2011) 'Forensic Science Service. Interview of Andrew Rennisson', HOC Science and Technology, Londres

Thompson, W. C. (2011) 'What Role Should Investigative Facts Play in the Evaluation of Scientific Evidence', Australian Journal of Forensic Sciences Vol 43 no 2-3, 123134 ,

Tilley, N. and A. Ford (1996) Forensic Science and Crime Investigation B. Webb (eds), Crime Detection and Prevention, Police Research Group, Home office, London, 73

Tilley, N. and M. Townsley (2009) 'Forensic Science in UK Policing: Strategies, Tactics and Effectiveness' in J. Fraser and R. Williams (eds), Handbook of Forensic Science, Willan, Cullompton, 359-379

van Nuijs, A. L. N., S. Castiglioni, I. Tarcomnicu, C. Postigo, M. L. de Alda, H. Neels, E. Zuccato, D. Barcelo and A. Covaci (2011) 'Illicit drug consumption estimations derived from wastewater analysis: A critical review', Science of The Total Environment Vol 409 no 19, 3564-3577, http://www.sciencedirect.com/science/article/pii/S0048969710005450

Vollmer, A. (1930) 'The Scientific Policeman', The American Journal of Police Science Vol 1 no $1,8-12$,

Vollmer, A. and A. Schneider (1917) 'The School for Police as Planned at Berkeley', Journal of the American institute of Crminal Law and Criminology Vol 7 no 6, 877898,

Walsh, S. J. (2009). Evaluating the Role and Impact of Forensic DNA Profiling on Key Areas of the Criminal Justice System, PhD Thesis, University Technology, Sydney.

Walsh, S. J. and J. Buckleton (2004) 'DNA Intelligence Databases(eds), Forensic DNA Evidence Interpretation, CRC Press, Boca Raton

Walsh, S. J., J. Buckleton and O. Ribaux (2009) 'The Continuing Evolution of Forensic DNA Databases' in F. González-Andrade (eds), Forensic Genetics Research Progress, Nova publishers, New York

Walsh, S. J., O. Ribaux, J. S. Buckelton, A. Ross and C. Roux (2004) 'DNA Profiling and Criminal Justice - a Contribution to a Changing Debate', The Australian Journal of Forensic Science Vol 36 no 1, 34-43,

Walsh, S. J., C. Roux, A. Ross, O. Ribaux and J. S. Buckleton (2002) 'Forensic DNA Profiling: Beyond Identification', Law Enforcement Forum Vol 2 no 3, 13-21,

Weyermann, C. and O. Ribaux (2012) 'Situating Trace in Time', Science and Justice Vol 52, 68-75,

White, J. H., D. Lester, M. Gentile and J. Rosenbleeth (2011) 'The Utilization of Forensic Science and Criminal Profiling for Capturing Serial Killers', Forensic Science International Vol 209 no 1-3, 160-165, http://www.sciencedirect.com/science/article/pii/S0379073811000351

Williams, R. and J. Weetman (2013) 'Enacting Forensics in Homicide Investigations', Policing and Society Vol 23 no 3, 376-389,

Wilson, D. B., D. McClure and D. Weisburd (2010) 'Does Forensic DNA Help to Solve Crime? The Benefit of Sophisticated Answers to Naive Questions', Journal of Contemporary Criminal Justice Vol 26 no 4, 458-469, 
